\title{
Complete remission of Merkel cell carcinoma on the upper lip treated with radiation monotherapy and a literature review of Japanese cases
}

\author{
Naoya Kitamura ${ }^{1 *}$, Riki Tomita ${ }^{1}$, Mayo Yamamoto ${ }^{1}$, Yasumasa Yoshizawa ${ }^{1}$, Eri Sasabe ${ }^{1}$, Tomohiro Yamada ${ }^{2}$ \\ and Tetsuya Yamamoto ${ }^{1}$
}

\begin{abstract}
Merkel cell carcinoma is a rare and aggressive neuroendocrine-derived skin cancer arising most commonly on the sun-exposed head and neck skin of elderly and immunocompromised patients. Although a combination of wide excision and adjuvant radiotherapy is the optimal therapeutic approach for Merkel cell carcinoma, radiation monotherapy has recently been recommended for unresectable tumors. We report here a case of Merkel cell carcinoma treated with radiation monotherapy and reviewed Merkel cell carcinoma cases treated with radiotherapy alone in Japan. A 75-year-old man was referred for treatment of a tumor on the upper lip with a swollen submental lymph node. The histopathological diagnosis from biopsied material was Merkel cell carcinoma (T3N1 bM0, stage IIIB). The submental lymph node was extirpated and radiation monotherapy was applied according to the 2014 National Comprehensive Cancer Network Guidelines because the Eastern Cooperative Oncology Group Performance Status of the patient was grade 3 and the patient and his family did not desire surgery. The primary site and bilateral upper neck regions were irradiated with 45 Gy followed by 20 Gy irradiation for the primary site alone. Three months after radiotherapy, the tumor seemed to have completely remitted. Approximately 1 year after radiotherapy, no evidence of local recurrence or late metastasis has been noted. Radiation monotherapy should be considered as a curative treatment for Merkel cell carcinoma, particularly in situations where extensive surgery is not favored.
\end{abstract}

Keywords: Merkel cell carcinoma, Radiation monotherapy, Head and neck, Unresectable tumor, Japanese patients

\section{Background}

Merkel cells are afferent sensory receptors that function as mechanoreceptors in the basal layer of the epidermis [1]. Merkel cell carcinoma (MCC) was first described in 1972 by Toker [2] and represents a rare and aggressive neuroendocrine-derived skin cancer that arises most commonly on the sun-exposed head and neck skin of elderly and immunocompromised patients. It has been debated whether MCC arises from malignant transformation of a Merkel cell [3] or from a pluripotent stem cell [4]. This malignancy shows a strong tendency for lymph node metastasis, distant metastasis, and recurrence, which are associated with poor prognosis. The 2014 National Comprehensive Cancer Network Guidelines [5] advocate

\footnotetext{
* Correspondence: nkitamura@kochi-u.ac.jp

${ }^{1}$ Department of Oral and Maxillofacial Surgery, Kochi Medical School, Kochi

University, Kohasu, Oko-cho, Nankoku city, Kochi 783-8505, Japan

Full list of author information is available at the end of the article
}

wide local excision with regional lymph node dissection and adjuvant radiotherapy, but definitive radiation monotherapy has recently been recommended for unresectable tumors, as MCC appears highly sensitive to radiotherapy [6-9]. We present here the case of a patient who achieved complete remission of MCC on the upper lip with neck lymph node metastasis using radiotherapy alone and review MCC cases treated with radiation monotherapy in Japan.

\section{Case presentation}

A 75-year-old man was referred for treatment of a $5 \times 4-\mathrm{cm}$ reddish nodule on the upper lip and a $2 \times 2$-cm lymph node in the submental region in December 2013 (Figure 1A,B). The medical past history of the patient was prostate cancer, cerebral infarction, and diabetes mellitus. Histopathological examination of the lip tumor revealed an aggregation of atypical tumor cells with scant cytoplasm and immunohistochemical positivity for CK20, AE1/AE3, synaptophysin, 


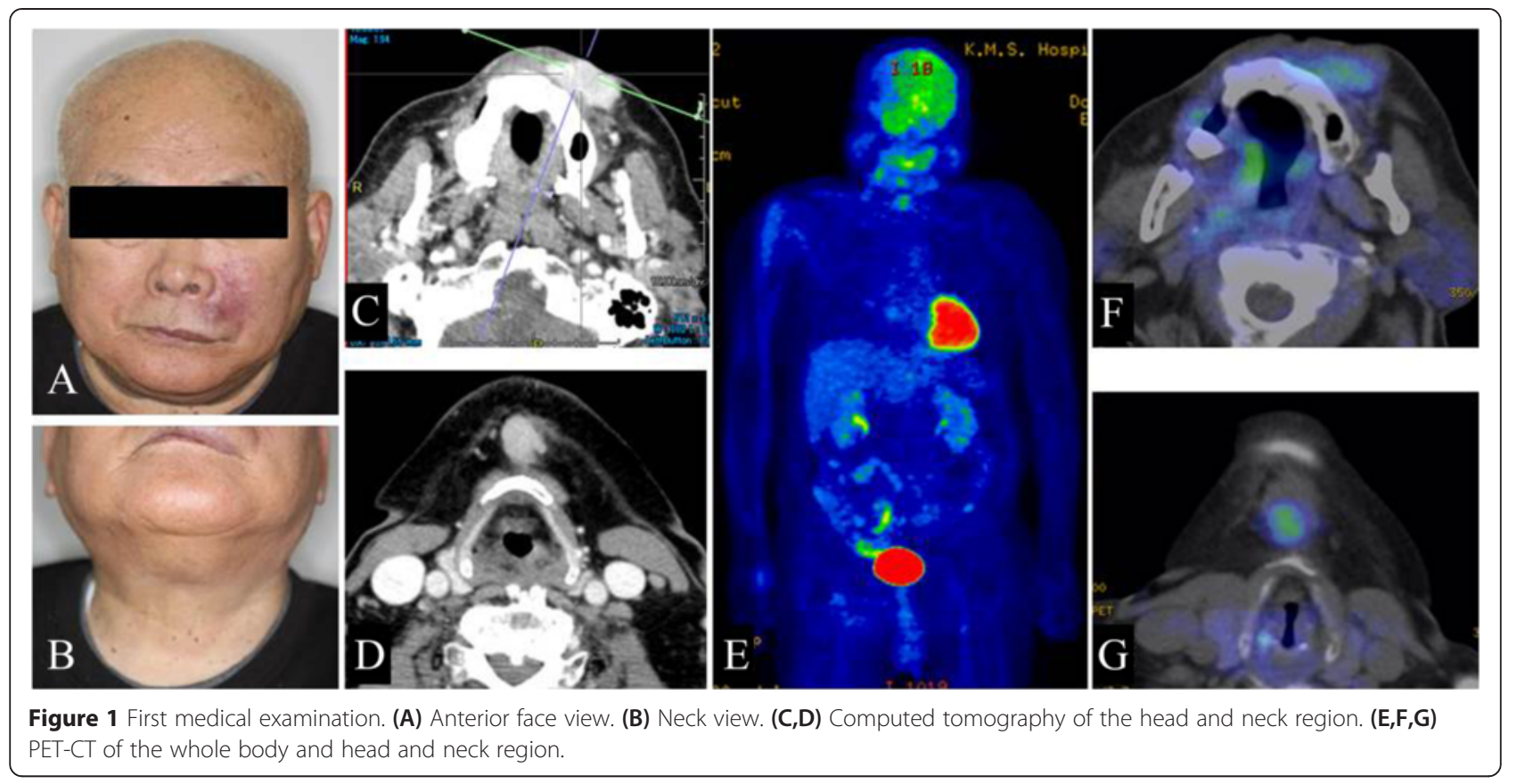

and CD58 (Figure 2). The tumor was diagnosed as MCC. Computed tomography indicated approximately $4 \times 3-\mathrm{cm}$ and $2 \times 2$-cm enhanced masses in the upper lip and submental region, respectively (Figure 1C,D). Hot spots of ${ }^{18}$ fluorodeoxyglucose on positron emission tomography were detected at the same sites seen on computed tomography (Figure 1E,F,G). The values of SUVmax in the primary site and submental lymph node were 3.4 and 3.3, respectively. According to the 2014 National Comprehensive Cancer Network Guidelines [5], the submental lymph
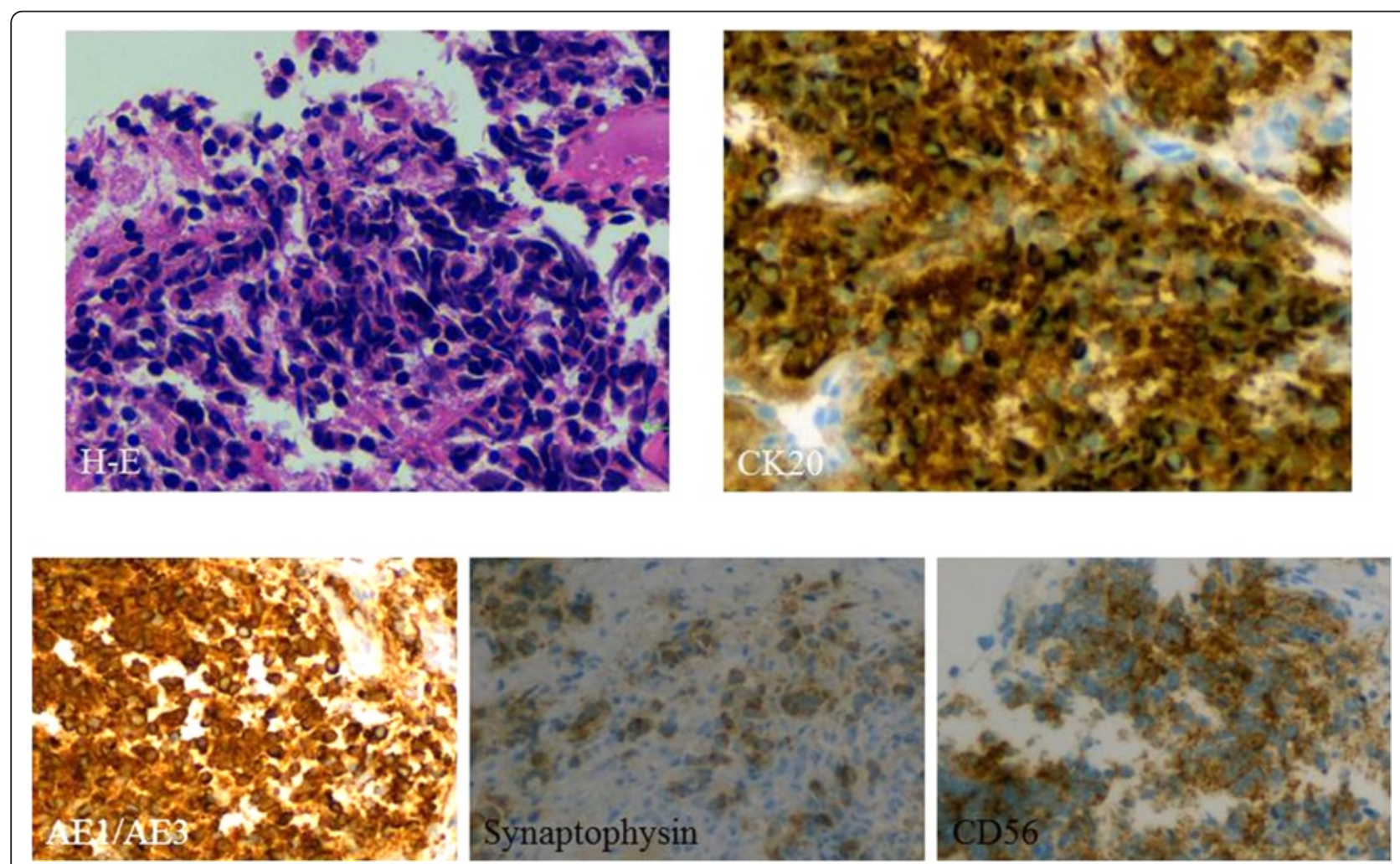

Figure $\mathbf{2}$ Immunohistochemical staining of metastatic MCC (primary specimen). 


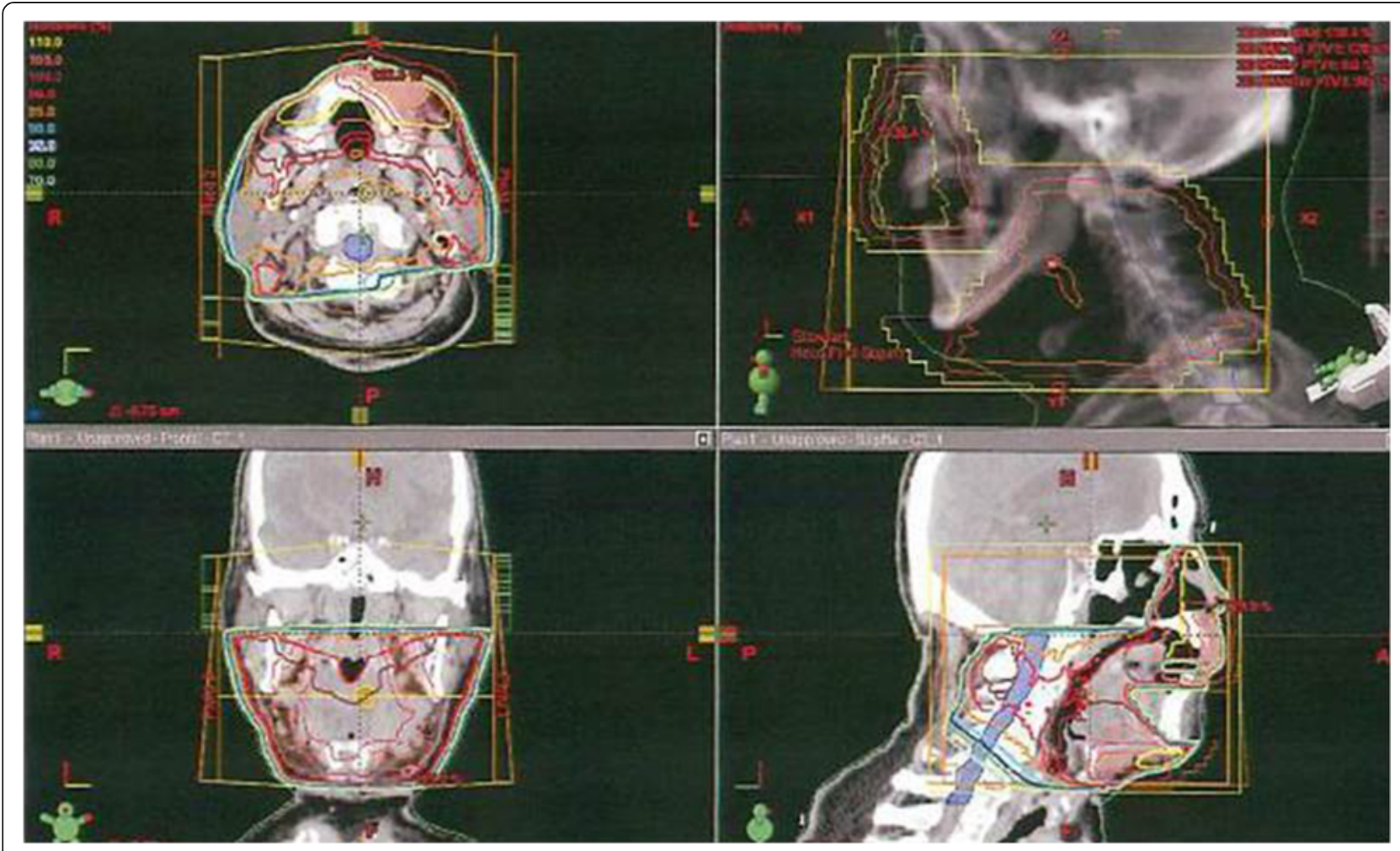

Figure 3 Field settings for radiotherapy. The patient received 4-MV linac X-ray, lateral parallel opposed paired ports for primary site and bilateral levels I and II (45 Gy/25 fr) plus electrons for the primary site alone (20 Gy/10 fr). Field margins were $\geq 2 \mathrm{~cm}$ around the lesion.

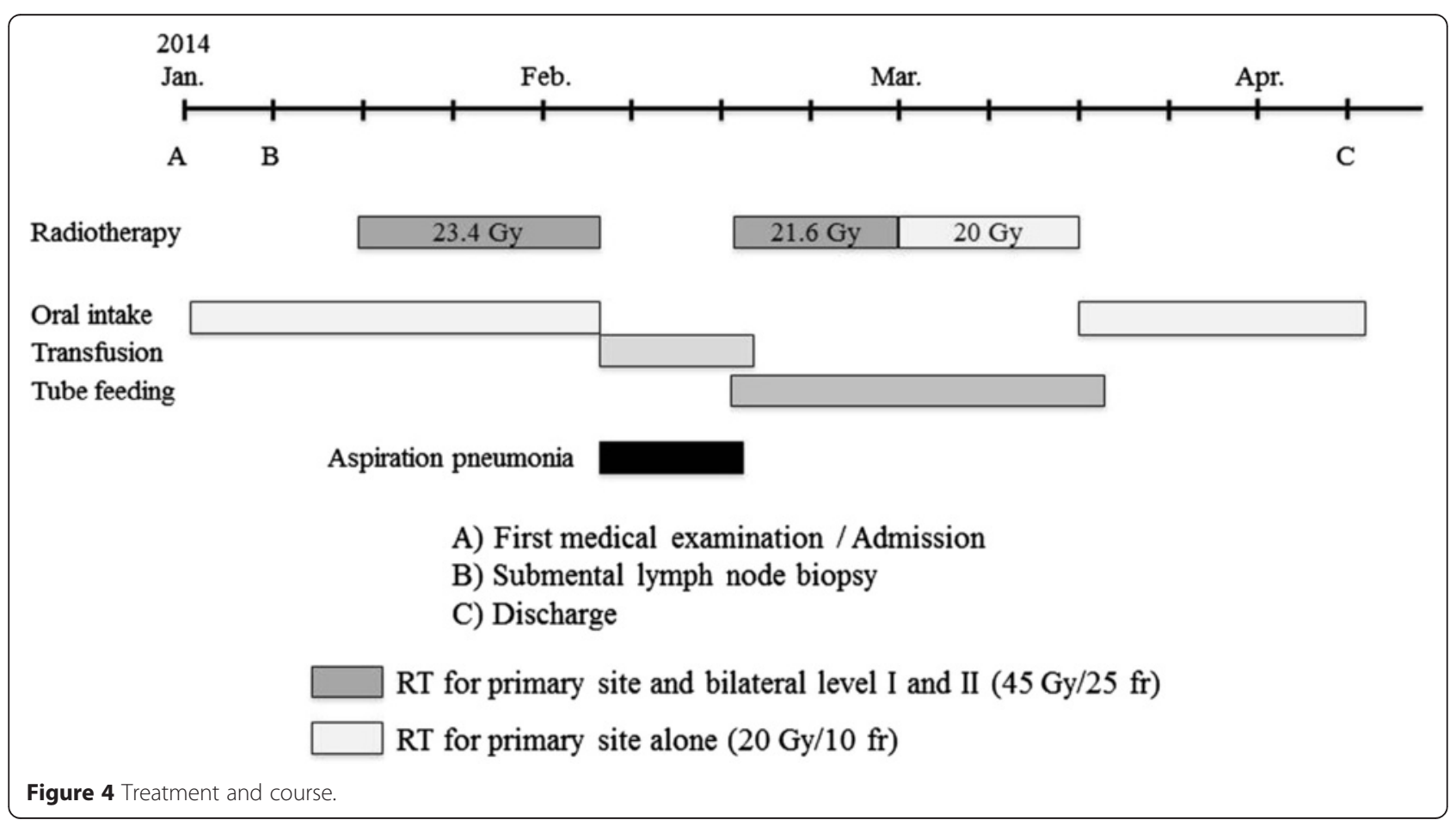



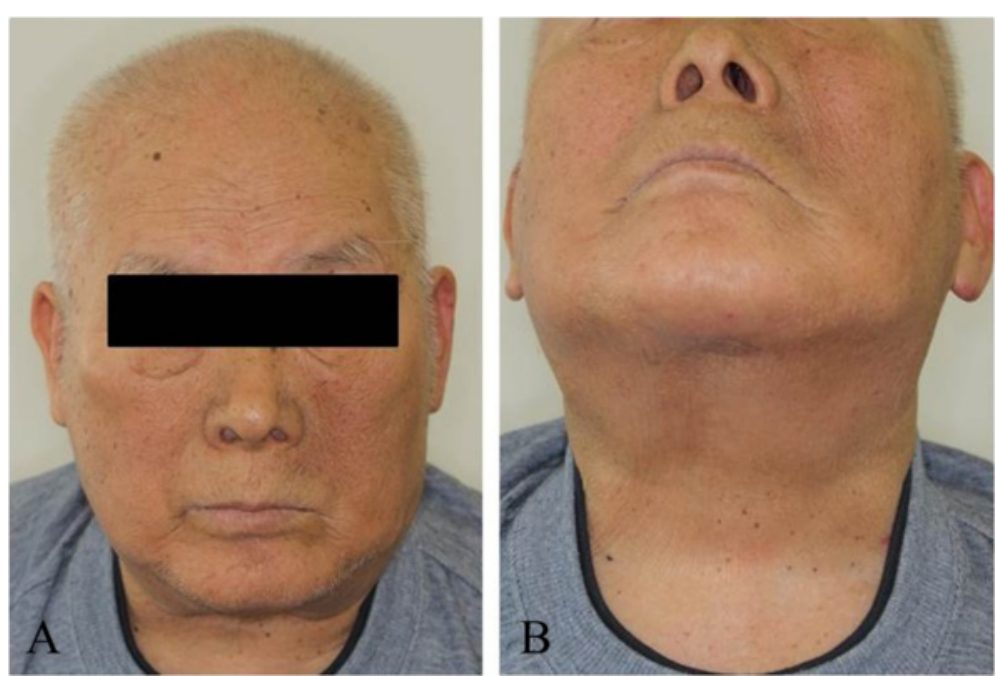

Figure 5 Nine months after radiotherapy. (A) Anterior face view. (B) Neck view.

Table 1 Merkel cell carcinoma treated with radiotherapy alone in the past 20 years in Japan

\begin{tabular}{|c|c|c|c|c|c|c|c|c|c|c|c|c|c|}
\hline \multirow[t]{2}{*}{ No. } & \multirow[t]{2}{*}{ Author } & \multirow[t]{2}{*}{ Year } & \multirow[t]{2}{*}{ Age/sex } & \multicolumn{2}{|l|}{ Sites } & \multicolumn{4}{|c|}{ Stage } & \multirow{2}{*}{$\begin{array}{l}\text { Dose } \\
\text { (Gy) }\end{array}$} & \multirow[t]{2}{*}{ Response } & \multirow[t]{2}{*}{ Recurrence } & \multirow{2}{*}{$\begin{array}{l}\text { F/U perioc } \\
\text { (months) }\end{array}$} \\
\hline & & & & $\mathrm{H} \& \mathrm{~N}$ & Limbs & $I$ & II & III & IV & & & & \\
\hline 1 & A. Aoki & 1995 & $90 \mathrm{~F}$ & 1 & & & & & 1 & 40 & SD & + & 0 \\
\hline 2 & H. Okada & 1995 & $83 \mathrm{~F}$ & 1 & & & 1 & & & 30 & $C R$ & + & 9 \\
\hline 3 & S. Nasu & 1997 & $88 \mathrm{~F}$ & 1 & & 1 & & & & 38 & $C R$ & & 14 \\
\hline 4 & K. Murata & 1997 & $89 F$ & 1 & & & 1 & & & 60 & $C R$ & & N/A \\
\hline 5 & T. Inoue & 1999 & $96 \mathrm{M}$ & 1 & & & 1 & & & 50 & $C R$ & & 4 \\
\hline 6 & Y. Handa & 2000 & $88 \mathrm{M}$ & & 1 & 1 & & & & 51 & $C R$ & & 9 \\
\hline 7 & H. Ono & 2001 & $78 \mathrm{~F}$ & 1 & & 1 & & & & 50 & $C R$ & & 9 \\
\hline 8 & S. Seki & 2003 & $60 \mathrm{M}$ & 1 & & & 1 & & & 56 & $C R$ & & 21 \\
\hline 9 & & & $69 F$ & 1 & & & 1 & & & 60 & $C R$ & & 5 \\
\hline 10 & N. Narita & 2004 & $96 \mathrm{M}$ & 1 & & & 1 & & & 66 & $C R$ & + & 1 \\
\hline 11 & E. Makino & 2005 & $84 \mathrm{~F}$ & 1 & & 1 & & & & 48 & $C R$ & & 8 \\
\hline 12 & T. Nakamura & 2005 & $83 \mathrm{~F}$ & & 1 & & & 1 & & 60 & $C R$ & + & 2 \\
\hline 13 & A. Niiya & 2006 & $72 \mathrm{~F}$ & 1 & & & & 1 & & 60 & $C R$ & + & 24 \\
\hline 14 & & & $66 \mathrm{~F}$ & 1 & & 1 & & & & 60 & $C R$ & & 18 \\
\hline 15 & T. Yamakawa & 2008 & $98 \mathrm{~F}$ & 1 & & & 1 & & & 36 & $C R$ & & 12 \\
\hline 16 & R. Maeda & 2010 & $86 \mathrm{~F}$ & 1 & & & 1 & & & 70 & $C R$ & & 19 \\
\hline 17 & J. Hujitaka & 2011 & $87 \mathrm{M}$ & 1 & & 1 & & & & 54 & $C R$ & & 32 \\
\hline 18 & K. Hanaoka & 2011 & $90 \mathrm{~F}$ & 1 & & & 1 & & & 28 & $C R$ & + & 4 \\
\hline 19 & A. Saito & 2012 & $90 \mathrm{~F}$ & 1 & & & 1 & & & 45 & $C R$ & & 12 \\
\hline 20 & & & $80 \mathrm{M}$ & 1 & & 1 & & & & 60 & $C R$ & & 22 \\
\hline 21 & & & $86 \mathrm{M}$ & & 1 & & 1 & & & 70 & $C R$ & + & 12 \\
\hline 22 & Present case & 2014 & $75 \mathrm{M}$ & 1 & & & & 1 & & 65 & $C R$ & & 12 \\
\hline & & & & 19 & 3 & 7 & 11 & 3 & 1 & $52.6 \pm 12.2$ & CR:21, SD:1 & $7 / 22$ & $11.0 \pm 8.4$ \\
\hline
\end{tabular}

$\mathrm{CR}$, complete response; $\mathrm{F}$, female; $\mathrm{F} / \mathrm{U}$, follow-up; $\mathrm{H} \& \mathrm{~N}$, head and neck; $\mathrm{M}$, male; NA, data not available; SD, stable disease.

Mean age $=83.4 \pm 9.9 ; 8$ males, 14 females. 
node was extirpated and the histopathological diagnosis of MCC was confirmed. TNM classification was diagnosed as T3N1bM0, stage IIIB. Treatment with radiation monotherapy was applied because the Eastern Cooperative Oncology Group Performance Status of the patient was grade 3, and the patient and family did not desire surgery. The primary site and bilateral upper neck (levels I and II) regions were irradiated with a dose of $45 \mathrm{~Gy} / 25 \mathrm{fr}$, followed by irradiation of $20 \mathrm{~Gy} / 10$ fr to the primary site alone (Figure 3 ). Field margins were generally $\geq 2 \mathrm{~cm}$ around the gross tumor volume. During the irradiation period, the planned radiation dose was accomplished using both infusion of electrolyte solution and tubal feeding, although the patient was forced to stop radiation therapy for approximately 10 days due to aspiration pneumonia (Figure 4). At 3 months after radiotherapy, the tumor seemed to show complete remission. As of approximately 1 year after radiotherapy, no evidence of local recurrence or late metastasis has been noted (Figure 5).

\section{Discussion}

MCC is a rare, aggressive, neuroendocrine-derived skin cancer that arises most commonly on the sun-exposed head and neck skin of elderly and immunocompromised patients. MCC at all body sites shows an incidence of around 0.6 per 100,000 capita, but this figure has been increasing over the past 20 years [10]. This malignancy shows a high tendency toward lymph node metastasis, distant metastasis, and recurrence, all of which are predictive of poor prognosis. The acronym "AEIOU" can be applied to describe the clinical features of MCC: asymptomatic/non-tender, expanding rapidly, immunesuppressed, older than 50 years, and ultraviolet-exposed fair skin $[11,12]$. The 2014 National Comprehensive Cancer Network Guidelines [5] advocate wide local excision (safe margin, $2 \sim 3 \mathrm{~cm}$ ) with regional lymph node dissection and adjuvant radiotherapy.

On the other hand, for unresectable cases, particularly in patients who would not tolerate wide surgical excision due to comorbidities, or where significant cosmetic or functional deficits would be incurred, definitive radiation monotherapy has recently been recommended, because MCC is highly sensitive to radiotherapy [6-9]. Pape et al. found no significant difference in 5-year disease-free and overall survival rates (approximately $90 \%$ each) between conventional therapy (surgery followed by radiotherapy) and radiation monotherapy for stage IB to IIB primary 25 MCC patients, respectively [6]. Medina-Franco et al. reported that the local relapse rate (LRR) was $10.5 \%$ when tumor excision and adjuvant radiotherapy was performed for 1,024 MCC patients [13]. Koh and Veness reported 1year LRR as $12.5 \%$ after performing radiation monotherapy for eight MCC patients [7]. Sundaresan et al. reported that 2-year LRR was $15 \%$ for 18 MCC patients receiving definitive radiotherapy [8]. Harrington and Kwan studied 179 MCC patients divided into two groups, with 57 receiving radical radiotherapy and 122 receiving radical surgery [9]. No significant differences in 5-year LRR (approximately $10 \%$ in each group) and 5-year nodal relapse rate (20\% $30 \%$ in each group) were seen between the groups.

According to the summary of radiation monotherapy cases reported in Japan, including the present case, that we were able to assemble from the past 20 years, complete response was achieved in 21 of 22 patients (95.5\%), and local relapse/late metastasis was seen in 7 of 22 patients (31.8\%) (Table 1) [14-30]. Only good cases may have been reported because all Japanese MCC cases were obtained from case reports. Even so, the results suggest that radiation monotherapy in Japan is an effective option, supporting the results of large-scale studies from other countries [6,10-12]. Furthermore, only three cases of radiation monotherapy for Japanese MCC stage III have been reported, including the present case (including two head and neck cases), and the two cases other than this case both showed recurrence (at 2 and 24 months). Careful follow-up will thus be essential in the present case.

\section{Conclusions}

Radiation monotherapy appears effective for the curative treatment of MCC and should be used, especially in situations where extensive surgery is not favored.

\section{Consent}

Written informed consent was obtained from the patient for publication of this case report and accompanying images. A copy of the written consent is available for review by the Editor-in-Chief of this journal.

\section{Abbreviations \\ CR: complete response; F: female; F/U: follow-up; H\&N: head and neck; LRR: local relapse rate; M: male; MCC: Merkel cell carcinoma; NA: data not available; SD: stable disease.}

\section{Competing interests}

The authors declare that they have no competing interests.

\section{Authors' contributions}

NK, RT, and MY managed the patient; NK, YY, and ES searched and reviewed the literature; and NK, TY, and TY wrote the paper. All authors read and approved the final manuscript.

\section{Acknowledgements}

We thank the patient for consenting publication of this case report.

\section{Author details}

${ }^{1}$ Department of Oral and Maxillofacial Surgery, Kochi Medical School, Kochi University, Kohasu, Oko-cho, Nankoku city, Kochi 783-8505, Japan. ${ }^{2}$ Section of Oral and Maxillofacial Surgery, Division of Maxillofacial Diagnostic and Surgical Sciences, Faculty of Dental Science, Kyushu University, Maidashi, Higashi-ku, Fukuoka 812-8582, Japan.

Received: 15 December 2014 Accepted: 26 March 2015

Published online: 17 April 2015 


\section{References}

1. Koljonen V. Merkel cell carcinoma. World J Surg Oncol. 2006:4:7. doi:10.1186/1477-7819-4-7.

2. Toker C. Trabecular carcinoma of the skin. Arch Dermatol. 1972;105:107-10.

3. Halata Z, Grim M, Baumann KI. The Merkel cell: morphology, developmental origin, function. Cas Lek Cesk. 2003;142:4-9.

4. Hewitt JB, Sherif A, Kerr KM, Stankler L. Merkel cell and squamous cell carcinomas arising in erythema ab igne. Br J Dermatol. 1993;128:591-2.

5. National Comprehensive Cancer Network (NCCN). Clinical practice guidelines in oncology: Merkel cell carcinoma; 2014. Available at: http://www.nccn.org/ professionals/physician_gls/f_guidelines.asp (accessed 9 Dec. 2014).

6. Pape E, Rezvoy N, Penel N, Salleron J, Martinot V, Guerreschi P, et al. Radiotherapy alone for Merkel cell carcinoma: a comparative and retrospective study of 25 patients. J Am Acad Dermatol. 2011;65:983-90.

7. Koh CSL, Veness MJ. Role of definitive radiotherapy in treating patients with inoperable Merkel cell carcinoma: the Westmead Hospital experience and a review of the literature. Australas J Dermatol. 2009;50:249-56.

8. Sundaresan P, Hruby G, Hamilton A, Hong A, Boyer M, Chatfield M, et al. Definitive radiotherapy or chemoradiotherapy in the treatment of Merke cell carcinoma. Clin Oncol. 2012;24:131-6.

9. Harrington C, Kwan W. Outcomes of Merkel cell carcinoma treated with radiotherapy without radical surgical excision. Ann Surg Oncol. 2014;21:3401-5.

10. Albores-Saavedra J, Batich K, Chable-Montero F, Sagy N, Schwartz AM, Henson DE. Merkel cell carcinoma demographics, morphology, and survival based on 3870 cases: a population based study. J Cutan Pathol. 2010;37:20-7.

11. Pellitteri PK, Takes RP, Lewis JS Jr, Devaney KO, Harlor EJ, Strojan P, et al. Merkel cell carcinoma of the head and neck. Head Neck. 2012:34:1346-54.

12. Heath $M$, Jaimes $N$, Lemos $B$, Mostaghimi A, Wang LC, Penas PF, et al. Clinical characteristics of Merkel cell carcinoma at diagnosis in 195 patients: AEIOU features. J Am Acad Dermatol. 2008;58:375-81.

13. Medina-Franco H, Urist MM, Fiveash J, Heslin MJ, Bland Kl, Beenken SW. Multimodality treatment of Merkel cell carcinoma. Ann Surg Oncol. 2001;8:204-8.

14. Aoki A, Yamada Y, Kimura S. A case of Merkel cell carcinoma. Jpn J Clin Dermatol. 1995;49:1117-20.

15. Okada H, Watanabe S, Takahashi H. A case of Merkel cell carcinoma: immunohistochemical analysis with anti-cytokeratin antibodies. Jpn J Dermatol. 1995:105:1445-50.

16. Nasu S, Hashida I, Sakurai H, Nagashima H, Katano S, Hayakawa K, et al. A case of Merkel cell carcinoma arising from the upper eyelid successfully treated with radiotherapy. Kitakanto Med J. 1997;47:91-4.

17. Murata Y, Maeguchi M, Nogita T, Kawashima M, Karasawa K. A case of Merkel cell carcinoma successfully treated with radiotherapy. Jpn J Clin Dermatol. 1997:51:373-6.

18. Inoue T, Tanita M, Ishizaki $Y$, Okada O, Sato T, Demitsu T, et al. A case of Merkel cell carcinoma successfully treated with radiotherapy. Jpn J Clin Dermatol 1997; 51: 373-376

19. Handa $Y$, Yamanaka N. A case of Merkel cell carcinoma of the antebrachium successfully treated with only radiotherapy. Skin Cancer. 2000;15:168-74.

20. Ono $\mathrm{H}$, Irimajiri K. A case of Merkel cell carcinoma successfully treated with electron-beam therapy. Jpn J Clin Dermatol. 2001;55:339-41.

21. Seki S, Shimada A, Arakura F, lijima M, Uhara H, Kawachi S, et al. Two cases of Merkel cell carcinoma of the upper eyelid treated by radiotherapy. Skin Cancer. 2003;18:22-7.

22. Narita N, Ohnishi Y, Tajima S, Wada N, Kobayashi T. A case of Merkel cell carcinoma. Rinsho Derma. 2004;46:4

23. Makino E, Sasae M, Sasaoka S, Inaoki M, Fujimoto W, Hiratsuka J. Radiation monotherapy for Merkel cell carcinoma: a case report and literature review of Japanese cases. Skin Cancer. 2005;20:329-33.

24. Nakamura T, Hashimoto S, Kato H, Furukawa H, Kaneko F. A case of Merkel cell carcinoma successfully treated with radiation monotherapy. Jpn J Clin Dermatol. 2005;59:1319-21

25. Niiya A, Yoshitomi E, Yamada A, Kashino K, Hamada T, Arakawa K, et al. Two cases of Merkel cell carcinoma successfully treated with radiation therapy. Nishinihon J Dermatol. 2006:68:154-7.

26. Yamakawa M, Mizuno M, Tokumaru A, Tanei R, Sawabe M. An elderly patient with Merkel cell carcinoma treated by twice-a-week electron therapy. Jpn J Clin Radiol. 2008;53:1023-7.

27. Maeda R, Moriue J, Fujita N, Yokoi I, Moriue T, Munehiro A, et al. Two cases of Merkel cell carcinoma. Rinsho Derma. 2009:51:1299-302.
28. Fujitaka J, Naito H, Masuoka H, Shigeyoshi N, Kawai K. Three cases of Merkel cell carcinoma of the face. J Jpn Plastic Reconstr Surg. 2011;31:380-6.

29. Hanaoka K, Matsumoto S, Ikeda M, Kumazawa S, Nakayama H. Parotid gland lymph node metastasis of Merkel cell carcinoma confirmed by aspiration cytology with immunocytochemistry. J J.jpn Soc Clin Cytol. 2011;50:301-2.

30. Saito A, Nakamura Y, Obara S, Nakamura Y, Kobayashi K, Fujisawa Y, et al. Three cases of Merkel cell carcinoma successfully treated with radiation monotherapy. Skin Cancer. 2012;27:373-8.

\section{Submit your next manuscript to BioMed Central and take full advantage of:}

- Convenient online submission

- Thorough peer review

- No space constraints or color figure charges

- Immediate publication on acceptance

- Inclusion in PubMed, CAS, Scopus and Google Scholar

- Research which is freely available for redistribution 